\title{
Alzheimer's disease and primary open-angle glaucoma: is there a connection?
}

This article was published in the following Dove Press journal:

Clinical Ophthalmology

27 June 20II

Number of times this article has been viewed

\author{
Fani Tsolaki' \\ Eleni Gogaki' \\ Sotiria Tiganita' \\ Christina Skatharoudi' \\ Chrysanthi Lopatatzidi' \\ Fotios Topouzis ${ }^{2}$ \\ Magdalini Tsolaki ${ }^{3}$ \\ 'Ophthalmology Department, \\ Hippokrateion General Hospital, \\ Thessaloniki, Greece; ${ }^{2}$ Ophthalmology \\ Department, Aristotle University of \\ Thessaloniki, Greece; ${ }^{3}$ Neurology \\ Department, Aristotle University of \\ Thessaloniki, Greece
}

Aim: To present, through a thorough literature research, current and older scientific efforts to investigate the putative association between Alzheimer's disease (AD) and glaucoma, especially primary open-angle glaucoma (POAG).

Methods: We included in our review article epidemiological, experimental and clinical laboratory studies.

Results: While many authors support the existence of a strong correlation between the AD and POAG, based on epidemiological, genetic and immunohistochemical data, others present contradictory results, leaving the issue unresolved.

Conclusion: Further research, probably targeted towards genetic parameters and based on large, multicenter studies has yet to be conducted. It is the authors' opinion however, that the existing data already justify the need for at least some degree of elevated clinical alertness for the occurrence of $\mathrm{AD}$ in patients with glaucoma and of glaucoma in patients with $\mathrm{AD}$.

Keywords: Alzheimer's disease, primary open-angle glaucoma, amyloid beta, apolipoprotein E, cerebrospinal fluid pressure, review article

\section{Introduction}

Alzheimer's disease (AD) is a neurodegenerative disorder which is one of the main causes of dementia worldwide. It gradually affects all fields of cognition, including short and long-term memory, executional capacity and behavior. Unfortunately, despite advanced and intense research, no definitive therapy is currently available. ${ }^{1}$ Glaucoma, one of the leading causes of blindness today, ${ }^{2,3}$ with 60 million persons affected and 8.4 million bilaterally blinded by the disease, ${ }^{3}$ is also a neurodegenerative disorder, characterized by degeneration of the retinal ganglion cells. The attempt to link these two disorders has been the focus of much research in recent years. The evidence-based establishment of such a connection would have a lot to offer in terms of increased clinical awareness, prophylaxis and early diagnosis of dementia for glaucoma patients and vice versa; it would also allow novel therapeutic approaches based on the knowledge of common etiology or causal relationship between the two conditions.

In this review article, we have examined important recent and older articles dealing with the subject, both epidemiological/clinical as well as experimental, in an effort to clarify the problem and highlight the need for further research in this direction. We have focused our interest on primary open-angle glaucoma (POAG), which is the most common form of the disease, and which, due to its unknown etiology, is most likely to share common ground with AD.
Correspondence: Fani Tsolaki Ophthalmology Department, Aristotle University of Thessaloniki, Anaximandrou 24, 54250,

Thessaloniki, Greece

Tel +30695717 II 48

$\mathrm{Fax}+302310912645$

Email gtagarakis@gmail.com 


\section{Studies}

\section{Epidemiological studies}

Chandra et $\mathrm{al}^{4}$ reported, based on a register study of US death certificates, an increased prevalence of glaucoma among patients who died bearing the official diagnosis of senile and presenile dementia. More recently, Bayer et $\mathrm{al}^{5}$ announced a higher prevalence of glaucoma among AD patients (25.9\%) in comparison to the prevalence observed in a control group of non-AD individuals (5.2\%). Tamura et $\mathrm{al}^{6}$ reached the same conclusion based on a larger prospective study sample, comprised of $172 \mathrm{AD}$ and 176 control individuals. The reverse relationship, that of an augmented occurrence of $\mathrm{AD}$ among glaucomatous patients, has also been investigated. Recently, Yochim et $\mathrm{al}^{7}$ found that more than $40 \%$ of a 41 -person sample of aged glaucomatous patients showed cognitive impairment, in the form of either memory impairment or executional dysfunction, but without an official diagnosis of AD. This fact has implications in the ability of these patients to comply with an adequate antiglaucoma regimen. However, the relationship between dementia and glaucoma could not be proven in a large study (sample size more than 11,000 subjects) performed by Kessing et al, ${ }^{8}$ which however had the major disadvantage of being a retrospective registerbased study. Similarly, Bach-Holm et al, ${ }^{9}$ in a recently published register-based study with a 20 -year follow-up that comprised 69 normal-tension glaucoma patients reported a lack of correlation of this disorder with $\mathrm{AD}$, as none of the enlisted patients developed AD.

\section{Experimental studies on animals}

As a disorder in the production and deposition of Amyloidbeta $(A \beta)$ in the brain, amyloid plaques are characteristics of Alzheimer's disease. Many researchers have focused their research on the role of $A \beta$ in the development of glaucoma. Guo et al, ${ }^{10}$ using a rat model experimental study, induced augmented intraocular pressure in male rats and found augmented amyloid beta aggregation in the affected retinal ganglion cells, a finding missing in the related cells of the contralateral, non-affected eyes. In a similar, more recent study, Kipfer-Kauer et al $^{11}$ managed to detect an amyloid regulating protein, called amyloid precursor protein (APP), as well as $A \beta$ in augmented concentrations in the optic nerves and retinal ganglion cells of rat eyes in which ocular hypertension was surgically induced. McKinnon ${ }^{12}$ also worked with a rat glaucoma experimental model, elucidating the role of apoptotic cell death through activation of a family of proteases, called caspases. These proteolytic enzymes (especially caspase-3 and caspase-8) act on APP to cause the production of neurotoxic fragments, which include $\mathrm{A} \beta$, thus providing an extra pattern of common etiology between $\mathrm{AD}$ and glaucoma at the cellular level. Vickers ${ }^{13}$ has also emphasized the role of cellular damage and cellular reaction to stress in the development of $\mathrm{AD}$ and glaucoma; He focused his studies on the neurofilament triplet, a group of cytoskeletal proteins accumulated in cases of damage to the larger retinal ganglion cells.

\section{Clinical-laboratory studies on humans}

A very interesting study that added a lot to the elucidation of the putative association between Alzheimer's disease and glaucoma was conducted by Gupta et al. ${ }^{14}$ The researchers used human ocular tissue specimens gained during glaucoma operations, and compared their immunohistochemical characteristics to those of living and postmortem control tissue specimens. They found that patients with unregulated intraocular pressure had decreased concentrations of normal tau-protein (BT2) and increased presence of abnormal hyperphosphorylated tau-protein molecules (AT8), especially within the posterior retina; such molecules can also be detected in the cerebrospinal fluid (CSF) of AD patients. In another clinical-laboratory study, Yoneda et $a{ }^{15}$ measured the A $\beta 42$ and tau-protein levels of the vitreous fluid in patients with retinal pathologies undergoing vitrectomy (including glaucomatous patients) and compared them to those of control patients. Patients with glaucoma had decreased levels of $A \beta$ and increased levels of tau-proteins in their vitreous fluid. This finding is possibly linked to the decreased levels of $A \beta$ and increased levels of tau-proteins in the CSF of $\mathrm{AD}$ patients.

Another possible link between $\mathrm{AD}$ and glaucoma lies in the CSF pressure, which appears to be decreased in $A D$ patients, a fact also observed among POAG patients. ${ }^{16}$ Ren et al, in two recent studies, ${ }^{17,18}$ which recruited patients with high-tension glaucoma, normal-tension glaucoma, patients with intraocular pressure without glaucoma and healthy subjects, highlighted the importance of the translaminacribrosa pressure difference in the development of at least one of the characteristic optic nerve damages of glaucoma, loss of neuroretinal rim (the others being deepening of the optic cup and parapapillary atrophy), and of the subsequent visual deficits. The translamina-cribrosa pressure difference may be a combination of normal intracranial/intraocular pressure and decreased CSF pressure or of an elevated intracranial/ intraocular pressure and normal CSF pressure. Berdahl and Allingham ${ }^{19}$ also highlighted the importance of reduced CSF pressure in the pathogenesis of glaucoma, in addition 
to the significance of elevated intracranial pressure in cases of high-tension glaucoma. Elevated intracranial pressure is also considered as a characteristic finding in AD. Wostyn et $\mathrm{al}^{22}$ addressed the quite complex issue of CFS pressure, $\mathrm{AD}$ and glaucoma: they correlated early stages of $\mathrm{AD}$ with elevated CSF pressure and later stages with decreased CSF pressure. They also highlighted the importance of a high translamina-cribrosa pressure difference in the development of glaucoma. ${ }^{20-22}$

\section{Apolipoprotein E gene and glaucoma}

An additional field of research into links between AD and glaucoma focuses on the apolipoprotein (APOE) gene and its variations. The gene is implicated in brain cholesterol and amyloid metabolism, and its APOE- $\varepsilon 4$ variation is regarded as one of the major predisposing factors for the development of AD. ${ }^{23}$ It is also responsible for decreased capacity of nerve cells in response to stress and for delayed rehabilitation after stroke or head trauma. ${ }^{24-26}$ This is the reason that many scientists have worked on the putative association of the gene with glaucoma. Zetterberg et $\mathrm{al}^{27}$ focused on the issue in a study of over 400 subjects and found no such correlation. Tamura et al, ${ }^{6}$ Ressiniotis et $a 1,{ }^{28}$ and Lake et $\mathrm{al}^{29}$ in older similar studies also obtained negative results, even for normal tension glaucoma, which would theoretically leave more "room" for genetic factors like APOE to work as glaucoma precipitating factors.

Al-Dabbagh et al, ${ }^{30}$ on the contrary, in a study performed on 230 Saudi individuals, found a positive correlation between the Apoe- $\varepsilon 4$ allele and the development of primary open-angle glaucoma, and, in addition, found a protective role of the $\varepsilon$ - 3 allele against the disease. Saglar et $\mathrm{al}^{31}$ also performed a genetic study on 75 patients with POAG and 119 control individuals and found no correlation between the polymorphisms of the APOE, tumor suppressor protein 53 (p53) and cyclin-dependent kinase inhibitor 1A (p21) genes on one hand and POAG on the other. However, Lam and associates ${ }^{32}$ concluded in a genetic study performed on 400 Chinese individuals that APOE- $\varepsilon 4$ is associated with glaucoma, but by acting as a protective factor against it.

Pseudoexfoliation glaucoma is a form of secondary glaucoma, which is characterized by ocular accumulation of fibrils containing amyloid-related proteins, thus probably sharing common features with AD. Krumbiegel et $\mathrm{al}^{33}$ however, in a meta-analysis comprising two European (one German and one Italian) cohorts, with over 1000 participants, found a negative correlation between APOE polymorphisms and this disorder.

\section{Conclusion}

Many important studies have supported the connection between $\mathrm{AD}$ and POAG. These data derive from epidemiological, experimental and clinical laboratory studies. These results, however, are contradicted by a series of other equally significant studies: this shows that the etiology of both AD and POAG is complex and warrants further focused investigation.

The existing data justify an elevated level of clinical awareness for the diagnosis of glaucoma in $\mathrm{AD}$ patients and vice versa. Hopefully, future research will shed light on the issue to the benefit of these two large categories of patients.

\section{Disclosure}

The authors report no conflicts of interest in this work.

\section{References}

1. Kalaria RN, Maestre GE, Arizaga R, et al. Alzheimer's disease and vascular dementia in developing countries: prevalence, management, and risk factors. Lancet Neurol. 2008;7(9):812-826.

2. Quigley HA. Glaucoma. Lancet. 2011;377(9774):1367-1377.

3. Quigley HA, Broman AT. The number of people with glaucoma worldwide in 2010 and 2020. Br J Ophthalmol. 2006;90(3):262-267.

4. Chandra V, Bharucha NE, Schoenberg BS. Conditions associated with Alzheimer's disease at death: case-control study. Neurology. 1986; 36(2):209-211.

5. Bayer AU, Ferrari F, Erb C. High occurrence rate of glaucoma among patients with Alzheimer's disease. Eur Neurol. 2002;47(3):165-168.

6. Tamura H, Kawakami H, Kanamoto T, et al. High frequency of openangle glaucoma in Japanese patients with Alzheimer's disease. J Neurol Sci. 2006;246(1-2):79-83.

7. Yochim BP, Mueller AE, Kane KD, Kahook MY. Prevalence of cognitive impairment, depression, and anxiety symptoms among older adults with glaucoma. J Glaucoma. 2011 Feb 17. [Epub ahead of print].

8. Kessing LV, Lopez AG, Andersen PK, Kessing SV. No increased risk of developing Alzheimer disease in patients with glaucoma. J Glaucoma. 2007;16(1):47-51.

9. Bach-Holm D, Kessing SV, Mogensen U, Forman JL, Andersen PK, Kessing LV. Normal tension glaucoma and Alzheimer disease: comorbidity? Acta Ophthalmol. 2011 Feb 18. [Epub ahead of print]

10. Guo L, Salt T, Luong Vy, Wood N, et al. Targeting amyloid- $\beta$ in glaucoma treatment. Proc Natl Acad SCi U S A. 2007;104(33): 13444-13449.

11. Kipfer-Kauer A, McKinnon SJ, Frueh BE, Goldblum D. 34 Distribution of amyloid precursor protein and amyloid-beta in ocular hypertensive C57BL/6 mouse eyes. Curr Eye Res. 2010;35(9):828-834.

12. McKinnon SJ. Glaucoma: ocular Alzheimer's disease? Front Biosci. 2003;8:s1140-s1156.

13. Vickers JC. The cellular mechanism underlying neuronal degeneration in glaucoma: parallels with Alzheimer's disease. Aust NZJ Ophthalmol. 1997;25(2):105-109.

14. Gupta N, Fong J, Ang LC, Yucel YH. Retinal tau pathology in human glaucomas. Can J Ophthal. 2008;43(1):53-60.

15. Yoneda S, Hara H, Hirata A, Fukushima M, Inomata Y, Tanihara H. Vitreous fluid levels of beta-amyloid((1-42)) and tau in patients with retinal diseases. Jpn J Ophthalmol. 2005;49(2):106-108.

16. Wostyn P, Audenaert K, De Deyn PP. An abnormal high trans-lamina cribrosa pressure difference: a missing link between Alzheimer's disease and glaucoma? Clin Neurol Neurosurg. 2008;110(7):753-754. 
17. Ren R, Jonas JB, Tian G, et al. Cerebrospinal fluid pressure in glaucoma: a prospective study. Ophthalmology. 2010;117(2):259-266.

18. Ren R, Wang N, Zhang X, Cui T, Jonas JB. Trans-lamina cribrosa pressure difference correlated with neuroretinal rim area in glaucoma. Graefes Arch Clin Exp Ophthalmol. 2011 Apr 1. [Epub ahead of print].

19. Berdahl JP, Allingham RR. Intracranial pressure and glaucoma. Curr Opin Ophthalmol. 2010;21(2):106-111.

20. Wostyn P. Can chronic increased intracranial pressure or exposure to repetitive intermittent intracranial pressure elevations raise your risk for Alzheimer's disease? Med Hypotheses. 2004;62(6):925-930.

21. Wostyn P, Audenaert K, De Deyn PP. The Valsalva maneuver and Alzheimer's disease: is there a link? Curr Alzheimer Res. 2009; 6(1):59-68.

22. Wostyn P, Audenaert K, deDeyn PP. More advanced Alzheimer's disease may be associated with decreased cerebrospinal fluid pressure. Cerebrospinal Fluid Res. 2009;6:14.

23. Huang W, Qiu C, von Straus E, Winblad B, Fratiglioni L. APOE genotype, family history of dementia, and Alzheimers disease risk: a 6-year follow-up study. Arch Neur. 2004;61(12):1930-1934.

24. Papassotirpoulos A, Wollmer MA, Tsolaki M, et al. A cluster of cholesterol-related genes confers susceptibility for Alzheimer's disease. J Clin Psychiatry. 2005;66(7):940-947.

25. McCarron MO, Weir CJ, Muir KW, Hoffmann KL, Graffagnino C, Nicoll JA, et al. Effect of apolipoprotein E genotype on in-hospital mortality following intracerebral haemorrhage. Acta Neurol Scand. 2003;107(2):106-109.
26. Brichtova E, Kozak L. Apolipoprotein E genotype and traumatic brain injury in children-association with neurological outcome. Childs Nerv Syst. 2008;24(3):349-356.

27. Zetterberg M, Tasa G, Palmer MS, et al. Apolipoprotein E polymorphisms in patients with primary open-angle glaucoma. $\mathrm{Am} J$ Ophthalmol. 2007;143(6):1059-1060.

28. Ressiniotis T, Griffiths P, Birch M, Keers S, Chinnery P. The role of apolipoprotein e gene polymorphisms in primary open-angle glaucoma. Arch Ophthalmol. 2004;122:258-261.

29. Lake S, Liverani E, Desai M, et al. Normal tension glaucoma is not associated with the common apolipoprotein E gene polymorphisms. $\mathrm{Br}$ J Ophthalmol. 2004;88(4):491-493.

30. Al-Dabbagh NM, Al-Dohayan N, ARfin M, Tariq M. Apolipoprotein E polymorphisms and primary glaucoma in Saudis. Mol Vis. 2009; 15:912-919.

31. Saglar E, Yucel D, Bozkurt Bozgul RK, Irkec M, Ogus A. Association of polymorphisms in APOE, p53, and p21 with primary open-angle glaucoma in Turkish patients. Mol Vis. 2009;15:1270-1276.

32. Lam CY, Fan BJ, Wang DY, et al. Association of apolipoprotein E polymorphisms with normal tension glaucoma in a Chinese population. J Glaucoma. 2006;15(3):218-222.

33. Krumbiegel M, Pasutto F, Mardin CY, et al. Apolipoprotein E genotypes in pseudoexfoliation syndrome and pseudoexfoliation glaucoma. J Glaucoma. 2010;19(8):561-565.
Clinical Ophthalmology

\section{Publish your work in this journal}

Clinical Ophthalmology is an international, peer-reviewed journal covering all subspecialties within ophthalmology. Key topics include: Optometry; Visual science; Pharmacology and drug therapy in eye diseases; Basic Sciences; Primary and Secondary eye care; Patient Safety and Quality of Care Improvements. This journal is indexed on Submit your manuscript here: http://www.dovepress.com/clinical-ophthalmology-journal

\section{Dovepress}

PubMed Central and CAS, and is the official journal of The Society of Clinical Ophthalmology (SCO). The manuscript management system is completely online and includes a very quick and fair peer-review system, which is all easy to use. Visit http://www.dovepress.com/ testimonials.php to read real quotes from published authors. 